\title{
Producing Biscuit as Complementary Food Enriched With Local Food Dadih for Stunted Children Aged 12- 24 Months
}

\author{
Helmizar $^{1 *}$ Resmiati $^{2}$, Yuliwarni ${ }^{2}$ \\ \{eelbiomed@gmail.com ${ }^{1}$, resmiati1989@gmail.com²,yuli_warni@yahoo.com³ \\ ${ }^{1-3}$ Department of Public Health Nutrition, Faculty of Public Health Andalas University, \\ Padang, Indonesia
}

\begin{abstract}
Stunting is a part of the wider nutrition crisis found in one out of four children under five in Indonesia. The purpose of this study is to create a complementary food enriched with local food Dadih and its effect on changes in consumption of stunted children aged 12-24 months. The product of this study was biscuits as complementary food enriched with Dadih. Its nutritional value per serving is $557.5 \mathrm{kcal}$ of energy, 17.3 grams of protein, 44 grams of fat, and 37.8 grams of carbohydrate. There was a change in the consumption of stunted children's nutrition in the two groups after the intervention. Still, it was not sufficient yet based on the recommended nutritional adequacy rates. The change in energy consumption in the intervention group was better than that of the control group. This type of product is good enough for stunted children as a complementary food.
\end{abstract}

Keywords: Acceptability, Local Complementary Food, Dadih, Stunting Children

\section{Introduction}

Stunting affected an estimated $22.2 \%$ or 150.8 million children under 5 globally in 2017 , dan 86.3 million of them are in Asia [1]. Stunting in Indonesia is the top five highest in Southeast Asia. In terms of absolute numbers, due to larger population size, Indonesia has by far the greatest number of stunted and wasted children under 5, over 9 million Indonesian children are stunted, and more than 4.5 million are severely stunted. At the same time, almost 3 million are wasted, and over a million are severely wasted. In Indonesia, stunting has remained relatively stable, no progress has been made, and its prevalence increased since 2010[2].

Indonesia Basic Health Research (Riskesdas) from year to year shows a matter of national concern. The prevalence of stunting in children under five increased from $36.8 \%$ in 2007 to $37.2 \%$ in 2013 and increased slightly to $30.8 \%$ in 2018 [3]. Besides, the results of monitoring the national nutritional status in 2017, there were $29.1 \%$ stunted children under five. In West Sumatra Province, the number of stunted children was above the national rate; it was $30.6 \%$ [4]. This figure is still far above the maximum limit of $20 \%$ set by WHO[5].

Stunting, or being too short for one's age, is defined as a height that is more than two standard deviations below the World Health Organization (WHO) child growth standards median. Stunting is the result of long-term nutritional deprivation and often results in delayed 
mental development, poor school performance, and reduced intellectual capacity. Women of short stature are at greater risk for obstetric complications because of a smaller pelvis. Small women are at greater risk of delivering an infant with low birth weight. It contributes to the intergenerational cycle of malnutrition, as infants of low birth weight or retarded tend to be smaller [5], [6].

Many factors cause malnutrition or stunting, especially in Asia, including food intake, LBW, and nutritional status of pregnant women, infectious diseases, breastfeeding practices, and feeding practices[2]. Although stunting is a complex condition influenced by numerous social and environmental factors, interventions to promote adequate complementary feeding practices in the first 2-3 years of life are the cornerstone of prevention and management. There are significant associations between complementary feeding practices and height-for-age $\mathrm{Z}$ scores (HAZ [7], [8]. Infants and young children need assistance that is appropriate for their age and developmental needs to ensure that they consume adequate amounts of complementary food. The proper number of feedings depends on the energy density of the local foods and the usual amounts consumed at each feeding.

The purpose of this study is to create a complementary food enriched with local food Dadih, its acceptability, and its effect on changes in consumption of stunted children aged 1224 months in the working area of the Air Dingin Health Center, Padang City. This product is expected to reduce the number of stunted children in Padang city.

\section{Introduction}

This study involved several stages namely; 1) optimization of the formula for making complementary food enriched with Dadih; 2) chemical analysis (nutrition), microbiology (lactic acid bacteria), and organoleptic tests; 3 ) producing complementary food (biscuits) enriched with local food Dadih on the scale of the pilot plan and product packaging design; 4) the trial phase of giving products to stunting children as an effort to optimize their growth.

The product of this study was complementary food in from of biscuits enriched with Dadih. The biscuits were prepared to meet the standard nutritional requirements for complementary food for children per day. Global Consultation Report (World Health Organization) states the MP-ASI requirement for children aged 12-24 months is $550 \mathrm{kcal}$ per day, due to breastfeeding alone can no longer meet the energy and nutrient requirements in optimizing children's growth and development.

After the product gets the right formula for nutritional, the process is carried out to the organoleptic tests. Three formulas are used in the organoleptic test, including Formula A, B, and C. The organoleptic test include smoothness, ease of swallowing, adhesiveness, color, aroma, and taste. The process of making biscuits enriched with Dadih and organoleptic tests will be carried out at the Nutrition Laboratory, Faculty of Public Health, Andalas University.

Children will do acceptability of food products under five in the working area of the Air Dingin Health Center, Koto Tangah District, Padang City using quasi-experiments, pre and post-test with control group design. The intervention group will be given complementary food biscuits enriched with Dadih, and the control group will be given complementary food biscuits without Dadih. Data analysis using paired sample t-test. 


\section{Result}

The complementary food formula in this study is made from local food raw material: corn flour, red bean flour, and soy flour called the F-JKK formula. The formula has been carried out by a proximate test to determine the nutritional value, such as carbohydrates, fat, protein, water, and ash content, which states that the formula for complementary foods is good for consumption. This complementary food formula was further developed into biscuits enriched with Dadih, the result of buffalo milk fermentation traditionally with bamboo.

The composition of biscuits as a local complementary food as a result of this study consists of cornflour, red bean flour, soy flour, eggs, butter, and sugar. The vla for biscuits is made from corn flour, liquid milk, butter, granulated sugar, and Dadih. Its nutritional value per serving is $557.5 \mathrm{kcal}$ of energy, 17.3 grams of protein, 44 grams of fat, and 37.8 grams of carbohydrate. It provides $45.5 \%$ additional energy and $66.5 \%$ protein based on the nutritional needs of children aged 1-3 years.

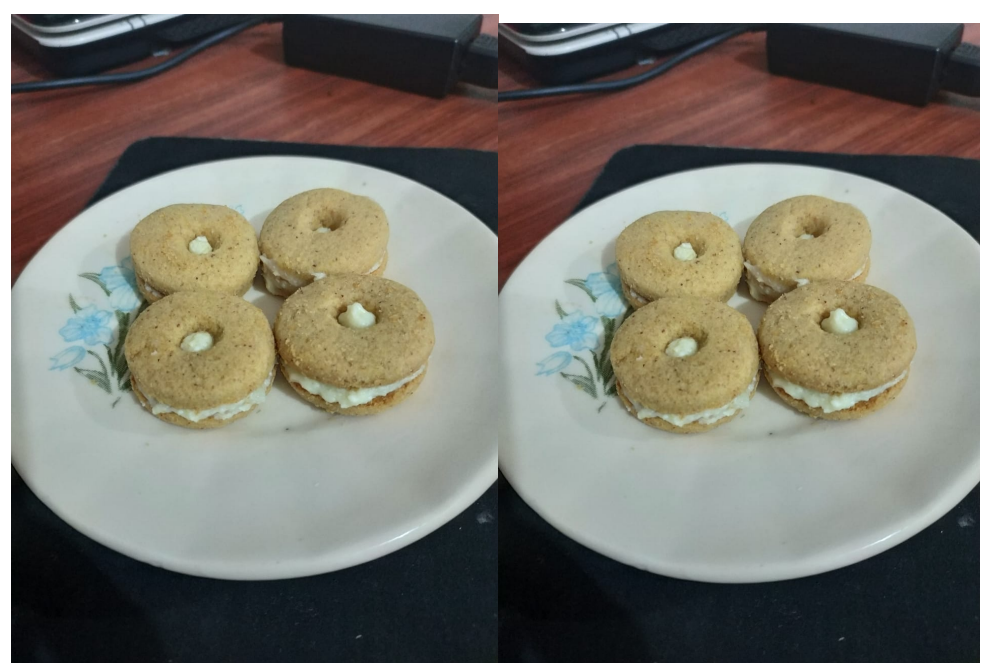

Fig.1. One portion of F-JKK biscuits enriched with Dadih as a complementary food for a day

The result of the organoleptic test on the three 3 formulas made shows that formula A gets the highest value as the panelist's most preferred product. It consists of 5 grams of Dadih, and it has a value of 3.9 or preferred at each rating point, such as color, taste, texture, and aroma.

The acceptance of biscuits can be seen from biscuits consumed by the children. In the intervention group, the number of biscuits consumed was $49.4 \%$. Whereas in the control group, the number of biscuits consumed was $47.8 \%$. Besides, the results showed a significant change in the consumption of nutrients from stunting children aged 12-24 months after the intervention. It can be seen in table 1 . 
Table 1. Average Changes in Nutrition Consumption Before and After Intervention

\begin{tabular}{cccc}
\hline \multirow{2}{*}{ Groups } & Before & After & \multirow{2}{*}{$\begin{array}{c}\text { Average Changes } \\
\end{array}$} \\
\cline { 2 - 3 } & Mean \pm SD & Mean \pm SD & $(\Delta)$ \\
\hline Intervention & & & \\
Energy & $554.6 \pm 209.9$ & $818.5 \pm 186.18$ & 263.9 \\
Protein & $17.12 \pm 4.13$ & $23.7 \pm 4.51$ & 6.6 \\
Fat & $19.9 \pm 10.6$ & $34.5 \pm 13.74$ & 14.6 \\
Carbohydrate & $68.8 \pm 16.98$ & $101.9 \pm 40.16$ & 33.1 \\
Control & & & \\
Energy & $511.9 \pm 192.8$ & $696.1 \pm 153.77$ & 184.2 \\
Protein & $17.2 \pm 3.21$ & $22.9 \pm 3.19$ & 5.7 \\
Fat & $23.7 \pm 9.57$ & $37.7 \pm 12.44$ & 14.0 \\
Carbohydrate & $54.5 \pm 31.3$ & $72.1 \pm 21.2$ & 17.6 \\
\hline
\end{tabular}

Table 1 shows the result of the analysis of respondents' nutrient consumption before and after the intervention. The analysis shows that the biggest change in consumption occurs in energy, which is $263.9 \mathrm{kcal}$.

\section{Discussion}

\subsection{Complementary Food}

WHO recommends that infants start receiving complementary food at 6 months of age in addition to breast milk. The transition from exclusive breastfeeding to family food, referred to as complementary feeding, typically covers the period from 6 to 18-24 months of age and is a very vulnerable period. It is the time when malnutrition starts in many infants, contributing significantly to the high prevalence of malnutrition in children under five [9].

Infants and young children need assistance that is appropriate to their age and developmental needs to ensure that they consume adequate amounts of complementary food. The appropriate number of feedings depends on the energy density of the local foods and the usual amounts consumed at each feeding. For the average healthy breastfed infant, meals of complementary foods should be provided 2-3 times per day at 6-8 months of age and 3-4 times per day at 9-11 and 12-24 months of age, with additional nutritious snacks (such as a piece of fruit or bread or chapatti with nut paste) offered 1-2 times per day, as desired [9]-[11].

Complementary Food "Biscuits" as a result of this study consists of cornflour, red bean flour, soy flour, eggs, butter, and sugar. Whereas the vla for biscuits is made from corn flour, liquid milk, butter, granulated sugar, and Dadih. The choice of material for making complementary food sourced from soy is because the protein content is quite high at $35-38 \%$ and in the form of flour up to $41.7 \%$. Meshing soy into flour will increase protein digestibility. It reduces antinutrients such as phytic acid and antitrypsin. Other sources of vegetable protein can be from red beans (Phaseolus vulgaris L), which is a type of bean that is enriched with 
nutritional content, especially as a source of carbohydrates, protein, and fiber that can be used to treat stunted children [12], [13].

Dadih added to this product because Dadih is a well-known local food and is widely consumed by ethnic Minangkabau, West Sumatra Province, Indonesia. In addition, Dadih is also a source of animal protein in this product. Nutritional substances in Dadih are also more easily absorbed because of the degradation of simpler proteins that are directly absorbed and utilized according to their functions. Probiotics in Dadih can also improve the surface of the digestive tract and increase body immunity, so that nutrient intake can be absorbed more optimally by stunting children [14], [15].

The nutritional value of biscuits per serving ( 8 pieces or 40 grams) is $557.5 \mathrm{kcal}$ of energy, 17.3 grams of protein, 44 grams of fat, and 37.8 grams of carbohydrate. It provides $45.5 \%$ additional energy, and $66.5 \%$ protein from nutritional needs for children aged 1-3 years. It is formulated to the estimated energy needs of complementary food set by WHO, which is 550 $\mathrm{kcal} /$ day for children aged 12-23 months [9].

\subsection{Acceptability of Complementary Food and Changes in Consumption of Stunting Children}

Three critical factors determine food acceptability. They include consumer characteristics, sensory characteristics, and enjoyment of food [16]. Food acceptability is a person's ability to consumed the food served compared to their needs or, in general, can also be seen from the amount of food consumed. Food acceptability can be measured using the Comstock scale visual estimation method[17].

Based on the biscuit acceptance test that has been carried out for 21 days, the results show that the average respondent in the intervention group (Biscuits enriched with Dadih) consumed half of the amount of local complementary food provided (49.4\%) or 4 pieces/day with energy $278.8 \mathrm{kcal}$ and 8.7 grams of protein. Whereas in the control group (Biscuits without Dadih), the figure was only about $1 \%$ different, respondents consumed as much as $47.8 \%$ of the total number of biscuits provided.

This study is in line with research conducted by Arnelia (2013), which states that there is no difference in the complementary food acceptability in the intervention group or the control group. The intervention group was able to consume as much as $73 \%$, and the control group $74 \%$. The average difference of additional food consumed by the two groups is only about $1 \%$ [18].

The results of this research are also in line with research conducted by Annis Catur Adi (2010). He stated that the average number of biscuits consumed daily by respondents is around 3.34 pieces per day in all treatment groups. It means the total number of biscuits consumed by respondents during the intervention, both in the control group and the treatment group, is relatively the same, or there is no meaningful difference in numbers [19].

From the interviews conducted with the respondent's mother, the reason for the existence of the remaining local complementary food biscuits provided was from internal and external factors. Internal factors such as children's appetite become very influential because most respondents have less appetite. Some of them only eat one or two times a day as much as 2 to 3 mouthfuls of rice one meal and do not consume vegetables and fruit. It can be seen from the amount of nutrient intake that it consumes only about $50 \%$ of the daily RDA for children aged 1-3 years.

External factors, such as consistency and size of the portion given, also affect the acceptability of local complementary food provided. Its consistency, which rather fragile, makes 
the biscuits break easily. The respondents tend to play with it. Eight pieces of biscuits were served every day ( $40 \mathrm{gr})$. It is too much for children, as the mother responded.

At this stage, the research is also considered the consumption of stunting children before and after the intervention. There was a change in the consumption of stunted children's nutrition in the two groups after the intervention. However, it was not sufficient based on the recommended nutritional adequacy rates (RDA). After the intervention, there were significant changes of energy, protein, fat, and carbohydrate consumption between the intervention and control groups, which is indicated by $\mathrm{p}$ values $<0.05$. Although the consumption of nutrition increased, it just provides $72.7 \%$ of energy, $91.1 \%$ of protein, $78.6 \%$ of fat, and $65.7 \%$ of carbohydrates.

\section{Conclusion}

The local complementary food in this study is biscuits made form local food raw material and enriched with Dadih. Its nutritional value per serving is $557.5 \mathrm{kcal}$ of energy, 17.3 grams of protein, 44 grams of fat, and 37.8 grams of carbohydrate. It provides $45.5 \%$ additional energy, and $66.5 \%$ protein based on the nutritional needs of children aged 1-3 years.

The acceptance test for stunting children in the Air Dingin Health Center, in Padang City showed that the biscuits consumed by respondents during the treatment in the intervention group (biscuit enriched with Dadih) were $49.4 \%$ and the control group (biscuits only) were $47.8 \%$. There was a change in the consumption of stunted children's nutrition in the two groups after the intervention, but it was not sufficient according to the RDA. The change in energy consumption in the intervention group was better than that in the control group. This type of product is good for stunted children as a complementary food. The product can be promoted as a complementary food for stunted children in Padang City.

\section{References}

[1] WHO, "Levels and Trend in Child Malnutrition," 2018.

[2] C. Chaparro, L. Oot, and K. Sethuraman, "Overview of the Nutrition Situation in Seven Countries in Southeast Asia,” Washington, DC: FHI 360/FANTA, 2014.

[3] Kemenkes, "Hasil Utama Riskesdas 2018," Jakarta, 2019.

[4] Kemenkes, "Hasil Pemantauan Status Gizi ( PSG ) Tahun 2017," Jakarta, 2018.

[5] WHO, "Nutrition Landscape Information System (NLIS) country profile indicators: interpretation guide," Geneva, Switzerland, 2010.

[6] WHO, "Global Nutrition Targets 2025: Stunting policy brief," 2014.

[7] B. Martinez et al., "Complementary feeding intervention on stunted Guatemalan children : a randomised controlled trial," BMJ Paediatr. Open, vol. 2, no. e000213, pp. $1-8,2018$.

[8] Z. A. Bhutta et al., "Maternal and Child Nutrition 2 Evidence-based interventions for improvement of maternal and child nutrition : what can be done and at what cost?," Lancet, vol. 382, pp. 452-77, 2013.

[9] WHO, "Complementary feeding: report of the global consultation, and summary of 
guiding principles for complementary feeding of the breastfed child," Geneva, Switzerland, 2002.

[10] Pan American Health Organization, "Guiding Principles For Complementary Feeding of The Breastfed Child," Washington DC: Pan American Health Organization, World Health Organization, 2003.

[11] World Health Assembly Resolution, "Infant and young child nutrition," WHA 54.2, no. May, pp. 2-5, 2001.

[12] H. A. Pangestu, "Karakterisasi Sifat Fisik dan Kimia Tepung Kacang Merah (Phaseolus Vulgaris L) dengan Beberapa Perlakuan Pendahuluan.," J. Teknosains Pangan, vol. 2, 2013.

[13] N. Q. Aini, "Kontribusi MP-ASI Biskuit Substitusi Tepung Garut, Kedelai, dan Ubi Jalar Kuning Terhadap kecukupan Protein, Vitamin A, Kalsium, dan Zink Pada Bayi," J. Nutr. Collage, vol. 2, 2014.

[14] Yuswita, "Dadih: Deskripsi, Manfaat, dan Standar Pembuatan," J. Univ. Andalas Padang, 2016.

[15] F. Arasj, "Pengaruh Pemberian Dadih (Susu Kerbau Terfermentasi) Melalui Makanan Tambahan Terhadap Status Gizi, Kejadian Diaree dan ISPA Anak Pendek (Stunted) Usia 1-4 Tahun," 'Afiyah, vol. 1, no. 1, 2014.

[16] J. W. Maina, "Analysis of the factors that determine food acceptability," Pharma Innov. J., vol. 7, no. 5, pp. 253-257, 2018.

[17] M. C. Gregoire, M.B., Spears, Foodservice Organizations: A Managerial and Systems Approach 6th ed. New Jersey: Pearson Education, 2007.

[18] Arnelia; Lilik Kustiyah; Mira Dewi; Dyah Santi Puspitasari, "Penerimaan Konsumen dan Complience Makanan Siap Makan Cookies Berbasis Bahan Lokal Untuk Anak Batita Wasting," Gizi Indon, vol. 36, no. 1, pp. 15-26, 2013.

[19] A. C. Adi, "Efikasi Pemberian Makanan Tambahan (PMT) Biskuit Diperkaya dengan tepung Protein Ikan Lele Dumbo (Clarias gareipinus), Isolat Protein Kedelei dan Probiotik Enterococcus faecium IS-27526 yang Dimikroenkapsulasi pada Balita (2-5 Tahun) Berat Badan Rendah,” Institut Pertanian Bogor, 2010. 